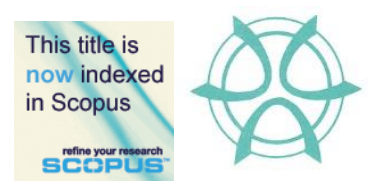

PLANNING MALAYSIA:

Journal of the Malaysian Institute of Planners

VOLUME 17 ISSUE 1 (2019), Page 186 - 195

\title{
IDENTIFICATION OF MACROECONOMIC FACTORS ON EXCESSIVE RETURNS: A LITERATURE REVIEW
}

\author{
Elsa Sapphira Victor ${ }^{1}$ \& Muhammad Najib Razali ${ }^{2}$ \\ Faculty of Geoinformation and Real Estate \\ UNIVERSITI TEKNOLOGI MALAYSIA
}

\begin{abstract}
Asian REITs could be considered as one of the fastest growing assets in the world. Japan is currently the biggest market in Asia and Asian REITs market is very much progressing to expand with the emerging of two major regional economies, China and India. Previous studies have proved that Asian REITs are able to show competitive advantage in most of mixed-asset scenarios and have significant roles in improving efficient global REITs portfolio returns. Previous findings also have shown that REITs are able to give remarkable return compare to other asset classes. Similar with other type of portfolio investment, REITs also have high interaction with macroeconomic factors such as inflation and interest rate which represent the economic situation of the countries. The excessive return is used to measure the performance that is affected by the macroeconomic factors by setting a benchmark which will give an added value to the portfolio. Hence, the aim of this research is to review on the literature of the macroeconomic factors on excessive returns Asian REITs.
\end{abstract}

Keywords: macroeconomic, REITs, Asian, return excessive 
PLANNING MALAYSIA

Journal of the Malaysia Institute of Planners (2019)

\section{INTRODUCTION}

Real Estate Investment Trusts (REITs) is a type of security that allows investors to access and participate in trading in the immovable property market on major exchanges without having to trade in physical assets. They can invest indirectly through companies which have assets and income related to real estate investment, and is qualified as a REIT. The types real estate include residential, industrial, retail, office, hospitality, logistics and any income generating property. REITs have favourable tax treatment, mandated dividends, lower perceived risk profile, offer diversification benefits in a mixed portfolio and have liquidity. This has caused investors to gain interest on REITs.

Unlike other listed real estate firms which commonly resell their real estate assets post-development, REITs acquire and/or develop real estate with the objective of operating them as part their investment portfolio (Kola \& Kodongo, 2017). From the beginning of US REITs in 1960, it has expanded widely all over the world including Asia Pacific in the late 1980s and now Asian REITs has become the second largest REIT market globally.

The performance of REITs is measured by the excessive returns which is the revenues obtained after deducting the risks that arise mainly from the macroeconomic factors. The situation of the macroeconomic factors represents the economic health of a country. Therefore, investors should first analyse the macroeconomic factors before making an investment decision as the returns of REITs are affected by them.

\section{RESEARCH BACKGROUND}

REITs have become a key component of the listed real estate markets, reaching a total market capitalisation of USD 1.3 trillion in June 2017, which represents $41 \%$ of the global listed real estate industry (EPRA, 2017). In recent years, investors are shifting towards Asian REITs which is the fastest growing market in the world and has overtaken France and UK. Asian REITs are more transparent compared to the mature US market and other established markets. This has given a sense of comfort and security to investors to invest in Asian REITs. This momentum gained has created an interest for researchers to study on Asian REITs.

Since 2005, the average total returns in emerging markets have been higher than developed markets $(9.20 \%$ vs $6.74 \%)$ and more recently ( $7.80 \%$ vs $4.63 \%$ ) over the past three years, and $28.40 \%$ vs $0.84 \%$ over the past year. The high returns have been confined almost exclusively to emerging markets in the Asia Pacific region while emerging markets in Europe and the Americas have posted negative returns (Mohamad \& Zolkifli, 2014). The rapid growth of Asian property market can provide opportunities for these global property securities fund to diversify their portfolio geographically and enjoy the higher return. According to Yue (2011), Asian REITs performed better than other 
Elsa Sapphira Victor \& Muhammad Najib Razali

Identification of Macroeconomic Factors on Excessive Returns: A Literature Review

key REIT markets in most of mixed-REITs scenarios, and saw their significant roles in improving efficient global REITs portfolio returns. The growing implementation of REITs in developing countries connotes increasing importance of the real estate market in developing economies. Real estate also offers a stable investment return and is a good hedge against inflation. Asian REITs also generate the highest yields across global REIT markets and some of the widest yield spreads over risk-free investments.

The real economy and its business cycles has been the subject of investigation of studies trying to understand the factors that drive REITs returns. The performance of REITs are measured by the returns and it is influenced by many factors mainly macroeconomic factors such as inflation, industrial production, money supply, exchange rate, interest rate and many more. Macroeconomic studies the performance and behaviour of economy by analysing the factors that influences the REITs returns. Companies can use these factors and create a model to help them strategized their investment. Yet, the relationship between macroeconomic factors and REITs has not been researched extensively in developing countries largely because REITs are a recent phenomenon in these economies.

Other than that, the macroeconomic factors are considered to be the risks that have to be measured by investors. In order to generate profit from the investment, it is important to calculate the excessive return which exceeds the rate of return that was expected. Excessive return is used to measure the riskadjusted performance by measuring how much risk from the macroeconomic factors is involved in producing that return. Hence, it is important to study the macroeconomic factors that will give an impact on the excessive returns of Asian REITs.

\section{ASIAN REITS}

In 2001, Japan (J-REITs) became the first Asian country to establish REITs. As of December 2017, there are 57 REITs listed in the Tokyo Stock Exchange and Osaka Stock Exchange with the market capitalization of USD103.5 billion and average dividend yield of $3.53 \%$. South Korea is the second Asian country after Japan to establish K-REITs with 42 listed companies in the Korea Stock Exchange. Then it was followed by Singapore (S-REITs) in 2002 with 39 listed companies in the Singapore Exchange Limited and in 2003, Taiwan (T-REITs) with 9 listed companies.

In 2003, Hong Kong (HK-REITs) was established and now has 8 listed companies; and in 2005 Malaysia established M-REITs with 18 listed companies in the Malaysia Stock Exchange. From the year 2007 to 2016, Hong Kong showed the highest sustainable growth performance and Malaysia REITs provided more stable dividend yield and return on asset performance among the other countries that were investigated (Azhar \& Noriza, 2017). The most recent country to 
PLANNING MALAYSIA

Journal of the Malaysia Institute of Planners (2019)

establish REITs is Thailand (Thai-REITs) in 2012. Although Thailand is the latest, it was quick to take off and has 50 listed companies in the Stock Exchange of Thailand.

According to Richard Price, a CBRE Global Investor, the growth opportunities in Asia are unique relative to almost all Western countries. This is because Asian REITs offer attractive investment features and benefits including liquidity and high yields, as well as unique features like Islamic REITs in Malaysia. REITs are publicly listed on the various major Asian stock markets. Asian REITs are actively traded in the same way as other shares on the stock market. Asian REITs are able to be readily bought and sold and enjoy a high level of trading turnover which means that it is sensitive to respond to the changes in the market.

Other than that, most Asian REIT markets require that at least $90 \%$ of the REITs taxable income must be returned to shareholders as a mandatory dividend pay-out to be classified as a REIT and be exempted from paying company tax. Often Asian REITs will actually distribute $100 \%$ of their taxable income as a dividend yield to shareholders. This means Asian REITs deliver attractive dividend yields that are significantly higher than normally seen with other types of shares. Any taxes to be paid are therefore only at the individual REIT shareholder level, resulting in most Asian REIT markets being tax transparent (Newell, 2012).

Asian REITs also have access to high quality income producing commercial real estate portfolios in sectors such as retail and hotel. Investors can either invest in sector specific REITs or diversify their portfolio which enhances their returns. Diversification can also be done in non-domestic real estate portfolios to provide exposure to other Asian markets and provide access to countries that have not established their own real estate market like China and India. Diversification by investing in different asset classes is a key portfolio management strategy in order to decrease investment risk as each asset classes perform differently in different market condition.

Asian REITs have strict regulatory structure with its requirements for corporate governance and financial reporting through audited financial statements and annual reports. A board of directors is also required to conduct annual general meeting and provide sufficient information in their website. This is to give full disclosure to the shareholders and the public. The operations of Asian REITs such as REIT funds management, portfolio management, asset management and property management are managed professionally by external and internal managers. Japan, Singapore, Malaysia and Thailand require external management structure whereas Hong Kong, Taiwan and South Korea require external and internal management structure. The management fees and securitization of Asian REITs is also lower than other companies listed on the stock market. 
Elsa Sapphira Victor \& Muhammad Najib Razali

Identification of Macroeconomic Factors on Excessive Returns: A Literature Review

Mature REITs markets like US and Australia proved to have a good track of performance over the past 50 years. However, Asian REITs which was only established 16 years ago managed to compete with those mature markets by showing strong returns, low to moderate risk, strong risk adjusted returns, diversification benefits and outperforming some stock markets.

\section{MACROECONOMIC FACTORS}

Asian REIT markets require acute observations of investors and accurate judgments regarding the macroeconomic environment. This requires investors to make assessment on the macroeconomic factors as it has an impact on the return. Many scholars have demonstrated that macroeconomic factors have significant influence on the returns of REITs. Ooi and Liow (2004) investigate the riskadjusted performance of property stocks in emerging markets of Hong Kong, Indonesia, Malaysia, Singapore, South Korea, Taiwan and Thailand report results indicating that the risk-adjusted performance of real estate assets is determined predominantly by macroeconomic factors.

West and Worthington (2006) used the GARCH model approach to empirically demonstrate that the macro-economy exhibits a significantly positive relationship with the return of REITs and that certain variables, such as the longrun interest rate, the short-run interest rate, unexpected inflation and the construction index, demonstrate particularly high correlations with commercial real estate returns. However, each macroeconomic factor has a different impact on different types of property portfolio.

Devaney (2001) also used the GARCH model to examine the influence of changes in interest rates on the excess returns of REITs and demonstrated that the yield of government bonds has a significantly negative relationship with the returns for both equity and mortgage REITs sectors. His study showed the macroeconomic factors have a different impact on the REITs sectors and the GARCH-M is more appropriate for the mortgage REITs than equity REITs. Therefore, it is important to test all the factors with all types of portfolios and sectors.

Another study carried out by Liow and Huang (2006) showed that the increase in the long-term interest rates is associated with lower excess returns. Although interest rate is one of the important factors affecting the excess returns on real estate, other factors include political stability, financial market deregulations, property supply and property prices and alternative investment opportunities also affect the excess returns.

In terms of inflation, according to Chan, Hendershott and Sanders (1990), and Chatrath and Liang (1998), stated that the studies of the relationship between REITs returns and inflation have not documented an unequivocal relationship. However, using the VAR model, Ewing and Payne (2005) empirically determined that inflation produces lower expected returns for REITs. Besides, the 
PLANNING MALAYSIA

Journal of the Malaysia Institute of Planners (2019)

unexpected shocks to inflation have an insignificant impact on excess returns on REITs, while Liow, Ibrahim and Huang (2006) found that the conditional volatility of an unexpected inflation is significant in explaining variations in listed real estate returns in some Asian-Pacific markets, although the direction of the effect varies by country.

Inflation is also caused by the global financial crisis. There are many studies on the performance of REITs during the financial crisis. The results of Huang, Wu, Liu and Wu (2016) show that as the global financial crisis occurred, there are high REIT-stock linkages and few diversification opportunities. Although Asia was deeply impacted by the financial crisis in 1997, it was not as impacted as the western countries in the global financial crisis in 2008 with Japan, Malaysia and Thailand being few of the least affected countries. This shows the capability of Asian REITs performance and returns despite the financial crises.

Other than that, inflation is measured by the consumer price index (CPI). Loo, Anuar and Ramakrishnan (2016) stated that all of the CPIs have significant influence on the developed REIT markets, indicating that investors are looking for inflation hedge when investing in the Asian markets. Inflation also gives an impact on the monetary policies. A study by Johnson and Jensen (1999) shows that a sudden monetary tightening lowers REIT returns for about a month after the shock. Meanwhile, Ewing and Payne (2005) stated that a monetary policy shock reduces REITs returns in the period following the shock. This is because unanticipated changes in the economy will cause a fall in REIT returns.

Other macroeconomic factors such as the gross domestic product (GDP) should be used to measure the performance of the economy of the countries. Naranjo and Ling (1997) found that the GDP or real per capita growth rate of consumption expenditures, the real Treasury bill, the term structure premium, and unanticipated inflation were significant on the real estate returns. Apart from that, Bilson, Brailsford and Hooper (2000) found that money supply, industrial production and exchange rates are significant with emerging equity returns. Therefore, these factors should also be investigated to find the significance with REITs returns.

In addition, REITs have a relationship with the stock markets. Liow, Zhou and Ye (2015) indicated that there are reasonable correlation dependencies between real estate securities and stock markets which are affected by macroeconomic factors. According to Fang, Chang, Lee and Chen (2016), the stock index has positive impacts on the REIT index in Japan, Singapore and China. Laopodis (2009) also investigated the interaction of REITs, the stock market and the real economy in the US market from 1971 to 2007 and found that REITs display similar characteristics to the movements in industrial production growth, implying that changes in policies impact the real economy, which in turn affect the returns on real estate stocks. 
Elsa Sapphira Victor \& Muhammad Najib Razali

Identification of Macroeconomic Factors on Excessive Returns: A Literature Review

Although these macroeconomic factors have a significant impact on REITs and are useful to forecast the returns, they do not behave the same for the direct property market. REITs are also able to absorb shocks to which they are exposed compared to the direct property investment. Hence, it is important to take note that these factors are only to be considered for indirect property investment which is REITs.

From the previous research findings, the main macroeconomic factors found to affect the excessive returns of Asian REITs are long term interest rates, short term interest rates, inflation, gross domestic product, construction index, industrial production, money supply, exchange rates and consumption risk. However, Loo et al. (2016) stated that the number of significant economic variables influencing the REIT markets is fewer in the short term as compared with the long run. Thus, it is important to test the REITs market for a longer period of time.

\section{EXCESSIVE RETURNS}

Most investors focus only on the returns but not on the total returns after considering the level of risk, tax, inflation and other macroeconomic factors. This can lead investors into poor portfolio decisions and misplacing expectations. Hence, it is important to focus on the excessive returns, rather than the nominal returns because excessive returns are used as measures of the added value by the portfolio. Excessive return, also known as 'alpha', is the return rate minus the risk-free rate which is the Treasury bill.

According to Johnson and Jensen (1999) the NAREIT indexes had higher returns than the S\&P 500 during expansive monetary periods, but all of the four (equity, mortgage, hybrid, and composite) NAREIT indexes underperformed the S\&P 500 during restrictive periods. However, the Treasury bills returns during restrictive periods were higher than during the expansive periods. Due to the differences of REITs and Treasury bills returns at different periods, it is necessary to calculate the returns in excess.

Additionally, investors should be more concerned about the return in excess of risk-free rate. According to Chen and Wang (2016), one of the important reasons most investors choose stocks instead of riskless Treasury bill is that they have the chance to get higher return as the compensation of undertaking the higher risk. If the return that investors get from the stock market is even lower than the risk-free rate, then they would only buy the Treasury bill and undertake no risk. Therefore, the excessive return of the Asian REITs companies should be higher than the risk-free rate in order to compensate the risk taken by investors.

There are many empirical studies that show significant relationships between economic conditions and excessive stock returns. For example, Fama and French (1989), and Whitelaw (1994) found a significant dependency 
PLANNING MALAYSIA

Journal of the Malaysia Institute of Planners (2019)

relationship in the conditional distribution of stock returns and business conditions. Chauvet and Potter (1998) also found a time-varying relationship between stock return and risk in regard to business cycle turning points. Although there are many research on the excessive stock returns, studies on excessive REITs returns is very limited. This has motivated the current research to explore further on the excessive returns of REITs.

\section{METHODOLOGY}

The research methodology was designed to comply with a sets of objectives. The REITs companies of Asian countries that will be researched on are Japan, South Korea, Singapore, Hong Kong, Taiwan, Thailand and Malaysia. The data that will be collected are the monthly total return, risk-free rate and macroeconomic factors. The risk-free rate varies according to the country as each country has its own rate. The risk-free rate is required in order to get the excessive return. The data will be retrieved from the literature review and Datastream over the period of 17 years which is from 2000 to 2017. Datastream is used to explore the relationships, trends, perform correlations and develop view points on the Asian REITs portfolio. It also helps to generate and test the portfolio. There are four techniques that will be used to analyse the data collected which are Factor Asset Pricing Model, Principal Component Analysis (PCA), GARCH $(1,1)$ Model and Generalised Method of Moments (GMM)

\section{EXPECTED OUTCOME}

This research is expected to find the macroeconomic factors that affect the excessive REITs returns to build up literature knowledge on the REITs market from the Asian and Malaysian market point of view. This research is also expected to discover the relationship between the macroeconomic factors and excessive returns of Asian REITs. Based on previous research, a positive relationship may be found between the variables (West \& Worthington, 2006). Some macroeconomic factors such as the interest rates, inflation and construction index may have a higher significant relationship and higher correlation with the excessive returns compared to other factors (Bilson et al., 2000; Liow et al., 2006; Loo et al., 2016; West \& Worthington, 2006). It is also expected to see how the macroeconomic factors affect and determine the excessive returns (Ewing \& Payne, 2005; Laopodis, 2009; Ooi \& Liow, 2004). Furthermore, the investigation on the excess returns rather than the nominal returns will provide information for an added value to the REITs portfolio.

\section{CONCLUSION}

The main driver of this research is to evaluate the excessive returns of Asian REITs that is affected by the macroeconomic factors. Asia is a large market and good investment opportunity for investors. Since much research has been done 
Elsa Sapphira Victor \& Muhammad Najib Razali

Identification of Macroeconomic Factors on Excessive Returns: A Literature Review

regarding the REITs in developed countries, this research will focus to REITs in Asian countries such as Japan, South Korea, Singapore, Hong Kong, Taiwan, Thailand and Malaysia. Therefore, this research will be useful for international investors to better understand the potential portfolio returns of investing in the Asian REITs market and help them choose which Asian country they should invest based on the current macroeconomic factors. Lastly, this research will enhance knowledge of the Asian REITs and its excessive returns and provide more information to the Malaysian government, especially on the REITs market, in order to enhance the performance of REITs in Malaysia in the future years.

\section{ACKNOWLEDGEMENT}

We thank the organiser for giving the opportunity to present this paper at the $9^{\text {th }}$ International Real Estate Research Symposium (IRERS).

\section{REFERENCES}

Azhar, N. E., \& Noriza, M. S. (2017). Financial performance of real estate investment trust (REITs): Evidence from Asian REITs. International Journal of Accounting, Finance and Business, 2(6), 167-175.

Bilson, C. M., Brailsford, T. J., \& Hooper, V. J. (2000). Selecting macroeconomic variables as explanatory factors of emerging stock market returns. SSRN Electronic Journal, 9(4), 401-426.

Chatrath, A., \& Liang, Y. (1998). REITs and inflation: A long run perspective. Journal of Real Estate Research, 16(3), 311-326.

Chan, K., Hendershott, P., \& Sanders, A. (1990). Risk and return on real estate evidence from Equity REITs. Real Estate Economics, American Real Estate and Urban Economics Association, 18(4), 431-452.

Chauvet, M., \& Potter, S. (1998). Economic turning points and stock market expectations - An empirical approach to the equity premium puzzle. Staff Paper, Federal Reserve Bank of New York.

Chen, C., \& Wang, Y. (2016). Understanding the multifractality in portfolio excess returns. Physica A: Statistical Mechanics and its Applications, 466(15), 346355.

Devaney, M. (2001). Time varying risk premia for real estate investment trusts: A GARCH-M Model. Quarterly Review of Economics and Finance, 4(3), 335-346.

European Public Real Estate Association [EPRA] (n.d.). Global REIT survey 2017.

Ewing, B. T. \& Payne, J. E. (2005). The response of real estate investment trust returns to macroeconomic shocks. Journal of Business Research, 58(3), 293-300.

Fama, E. F., \& French, K. R. (1989). Business conditions and expected returns on stocks and bonds. Journal of financial economics, 25(1), 23-49.

Fang, H., Chang, T. Y., Lee, Y. H., \& Chen, W. J. (2016). The impact of macroeconomic factors on the Real Estate Investment Trust Index return on Japan, Singapore and China. Investment Management and Financial Innovations, 13(4), 242-253.

Huang, M., Wu, C. C., Liu, S. M., \& Wu, C. C. (2016). Facts or fates of investors' losses during crises? Evidence from REIT-stock volatility and tail dependence structures. International Review of Economics \& Finance, 42, 54-71. 
Johnson, R. R., \& Jensen, G. R. (1999). Federal Reserve monetary policy and real estate investment trust returns. Real Estate Finance, 16(1), 52-59.

Kola, K., \& Kodongo, O. (2017). Macroeconomic risks and REITs returns: A comparative analysis. Research in International Business and Finance, 42, $1228-1243$.

Laopodis, N. (2009). REITs, the stock market and economic activity. Journal of Property Investment \& Finance, 27(6), 563-578.

Liow, K. H., \& Huang, Q. (2006). Interest rate risk and time-varying excess returns for Asian property stocks. Journal of Property Investment \& Finance, 24(3), 188 210.

Liow, K. H., Ibrahim, M. F., \& Huang, Q. (2006). Macroeconomic risk influences on the property stock market. Journal of Property Investment \& Finance, 24(4), 295323.

Liow, K. H., Zhou, X., \& Ye, Q. (2015). Correlation dynamics and determinants in international securitized real estate markets. Real Estate Economics, 43(3), 537585.

Loo, W. K., Anuar, M. A., \& Ramakrishnan, S. (2016). Integration between the Asian REIT markets and macroeconomic variables. Journal of Property Investment \& Finance, 34(1), 68-82.

Mohamad, N. E. \& Zolkifli, I. A. (2014). The determinant factors of real estate investment trust (REIT)'s performance: Evidence from Asian REITs. Indonesian Capital Market Review.

Naranjo, A., \& Ling, D. C. (1997). Economic risk factors and commercial real estate returns. The Journal of Real Estate Finance and Economics, 14(3), 283-307.

Newell, G. (2012). Asia Pacific real estate association- APREA.

Ooi, J., \& Liow, K. H. (2004). Risk-adjusted performance of real estate stocks: Evidence from developing markets. Journal of Real Estate Research, 26(4), 371-396.

West, T., \& Worthington, A. C. (2006). Macroeconomic risk factors in Australian commercial real estate, listed property trust and property sector stock returns. Journal of Financial Management of Property and Construction, 11(2), 105-116.

Whitelaw, R. F. (1994). Time variations and covariations in the expectation and volatility of stock market returns. The Journal of Finance, 49(2), 515-541.

Yue, W. (2011). The Development of Real Estate Investment Trusts in Asia (Master's thesis). University of Western Sydney, Australia

Received: $28^{\text {th }}$ October 2018. Accepted: $1^{\text {st }}$ March 2019 